\title{
Participation of Teachers in the Development of Basic Islamic Schools under the Association of Muslim Ethics in Thonburi, Bangkok
}

\author{
Dr Prasert Suksaskawin \\ Centre of Islamic Studies, Siam Technology Collage, Bangkok
}

\begin{abstract}
Education is very important for human life and Islam gives full attention towards education and for creating learning environment which needs management and regulations of religious bodies and to support basic education to the society and community. In Thailand there is an Islamic regulatory bodies and the association of Muslim ethics is one of them which deal to management aspect of basic Islamic education. In this research, the author focuses on the attributes of management by Muslims of Shia sect of Islam. The main aim of this research is compare the Muslim of Shia sect of Islam those established a club beneficial to society based on Shia Muslim sect and have gathered data from of mosques and religious organizations of the Muslim Shia where basic Islamic education is provided to the society.
\end{abstract}

Keyword: Islamic, Muslim, ethics, society, etc.

\section{Introduction}

Islam means 'Peace' and true peace in terms of internal and external feelings which comes when someone surrender to God and be obedience with acts in all walks of life for real peace to mind. Muslim is a word of Arabic means having spirit for surrendering to God. Being a Muslim everything carries for a society and society is an institution of individuals which role are very much responsible through duties they have to serve for needs of society. There is for functioning for better society which requires social institutions, political institutions, educational institutions, religious institutions and economic institutions. When society acts with organizing, guiding and performing their duties in an appropriate manner then consistent social environment emerge.

Education is a very important for individuals' progress. It helps individuals to get ideas, intellectuality, morality, ethical values, and good things in life which can be apply in right way. Education gives understanding and knowing circumstances and changes in the different parts of society. The nations can develop and prosperous through education and people in society get good and comfortable lifestyles. The lack of basic education makes a person blind in life. There is a main aim to focus on education is the process of developing the whole person in minds, habits and other features and it fits from one generation to another generation. In Addition, education is a tool of the state to create a unity among citizens which contributes to the stability of the state as well as the needs of the social, cultural, economic and political setup of the state.

Education is a process of intellectual and moral components to help for those who are oppressed in the society and bring best life to the people who are well equipped with education. Dedicated management is required for lifelong learning approach in the society and in Thailand to build society of learning there are 
guidelines for creating a knowledge society are needed. At the community level, the process of learning needs well organized by associated organizations and maximum use of technical services for beneficial and development of the community. The life-long learning approach in society of Thailand leads to fulfill the wisdom of Thailand towards progress of society.

Every Muslim must be part of learning whether the religious knowledge or worldly knowledge especially to learn story of salvation and the purpose of learning to faith and devotion for God. Manage religious learning in Islam is the fundamental duty of Muslims for supporting basic education to the society and community. Learning and understanding of religion through teaching happens since early childhood because education is essential for human life. There is lack of quality people if people are uneducated and in Islam there is God says human being learns from the cradle to the grave. In this regard every Muslim must be obliged to seek for knowledge. The duty of Muslims must be royalty to God and engage themselves in the learning of sciences in order to live in this world. Education is an area to make people success in this world and next world and at the same time every Muslim must learn for life as per guideline of Quran.

\section{Research Objectives}

a) To study the involvement of teachers of Association of Muslim Ethics in the development of basic Islamic Schools in Thonburi, Bangkok.

b) To compare the contributions of Muslim Shi'a Islam to manage basic education in Thonburi, Bangkok in the areas of personality, Administrators, parents, and community leaders.

\section{Variables}

\begin{tabular}{|l|l|}
$\begin{array}{l}\text { The status of the } \\
\text { individual, Community } \\
\text { School Administrators, } \\
\text { Teacher, Community } \\
\text { leaders, parent }\end{array}$ & $\begin{array}{r}\text { Participation in the development of } \\
\text { the four areas in schools. } \\
1 .\end{array}$ \\
& The administrative and \\
educational support. & Course \\
3. & Process \\
4. Resources and investment & to education. \\
\hline
\end{tabular}

This research conducts on teachers in the development of the basic Islamic schools in Thonburi, Bangkok under the Association of Muslim Ethics. The aim of this research is to study the involvement of teachers and Muslims of Shia sect of Islam to manage the basic education in Thonburi, Bangkok. And also compare the contributions of Muslim Shia sect of Islam to manage basic education in Thonburi Bangkok under Association of Muslim ethics. The data on personality were collected from community leaders, parents, students and teachers and administrators from the association of Muslim ethics. For sampling use of 80 to conducted and analyzed the date with the 
use of frequency, percentage, average, standard deviation and software packages SPSS XI for Windows (Statistical Package for Social Sciences Version XI).

\section{Summary and Suggestions}

This study deals with the expectations of the Muslim Shia sect of Islam in the management of basic education under the association of Muslim ethics in Thonburi, Bangkok. There are important issues to be discussed which include the curriculum of Islamic education and assessment of philosophy of the course. This study found that the expectations of Shia Muslim for parents, community leaders, teachers and executive committee of the association of Muslim ethics are high. This results due to curriculum and philosophy of courses in Islamic education. This study found the overall expectations are low in nature due to less budget obtained from the association of Muslim ethics which is really concern for managing various aspects of schools. This study also found community leaders, teachers and the board of directors of the Association of Muslim ethics of Shia Muslim is a matter of priorities.

\section{References and Bibliography}

[1] Kanjanacnaraks (1992), Curriculum Deverlopment, 2nd edition Genesis: Printing Silpakorn University.

[2] KriengsakChareonwongsak (2000), South wise Educators, Edition 4: A blockade net Dhaka printing.

[3] Religious Affairs (1992), Registration mosque in Thailand, The degree Snoopy Waithayopathum,Bangkok

[4] Sheikh Sharif Hadi (2009), Foundation Imam al-Hadi (as), Grade 5 textbook Islam Bangkok.

[5] Sheikh Sharif Hadi (2009), Foundation Imam al-Hadi (as), textbook Islam grade 6 Bangkok.

[6] Seiji Tanaka (1995), Development of the historical Muslim Community School. Bangkok: (Mimeograph document), Institute of Asia-Pacific Studies, Srinakharinwirot University. 